\title{
Phosphorus availability in residues as fertilizers in organic agriculture
}

\author{
Bente Foereid \\ Norwegian Institute of Bioeconomy Research, Pb 115, NO-1431 Ås, Norway \\ e-mail: bente.foreid@nibio.no
}

\begin{abstract}
Phosphorus (P) should be recycled from organic wastes as much as possible, and input is needed in stockless organic agriculture. Seven organic residues were assessed and compared them to mineral $P$ fertilizer and rock phosphate as fertilizer for barley. $\mathrm{P}$ availability in the mixtures and residual $\mathrm{P}$ availability were also assessed by diffusive gradients in thin films (DGT). The best availability was found in digested liquid manure followed by wood ash, fish sludge, composted solid manure and composted food waste. Meat and bone meal, the commercially available product Ladybug plus and rock phosphate had low $\mathrm{P}$ availability at the same level as no P. Only wood ash had significant $P$ available for the next crop. The $\mathrm{pH}$ level of the soil did not affect $\mathrm{P}$ availability for any of the $\mathrm{P}$ sources. DGT predicted $\mathrm{P}$ availability moderately well, as it measures $\mathrm{P}$ supply over a short period without any biological factors.
\end{abstract}

Key words: phosphorus, organic waste, fertilizer, DGT

\section{Introduction}

Phosphorus (P) is an element necessary for life, and the world's supply of $\mathrm{P}$ is finite. Current calculations suggest that easily exploitable P reserves will be depleted within 50-100 (Cordell et al. 2009) to 300-400 years (van Kauwenbergh 2010). At the same time $P$ in waste materials and surplus fertilizer are causing eutrophication of fresh water and coastal areas (Carpenter et al. 1998, Cordell et al. 2009). A sustainable society will need to reduce waste of $P$ and recycle most of its $P$ from organic residues (Cordell et al. 2011).

Organic farming does not permit the use of inorganic fertilizers, and therefore introduces a further incentive to recycle $P$ from residues or allowed supplements, such as rock phosphate. The ideal would be recycling on the farm itself, but as $P$ is exported with produce, calculated $P$ balances indicate that more $P$ is removed with the products than applied as fertilizer (Watson et al. 2002, Berry et al. 2003). Whilst farms with animal production usually import $P$ with feed and often accumulate $P$ in the soil, farms with only arable production will need to replenish $P$ lost with export of produce. Replenishing $P$ with residues from wider society or from other farms with animal production makes a circular P economy on a larger scale. To manage such a system in a safe and efficient manner information on fertilizer value as well as any potentially harmful effects of each residue is needed.

A challenge in managing plant $P$ supply is estimating the bioavailability of $P$ in soil and residues/supplement. $P$ can occur in numerous inorganic and organic compounds and bioavailability varies among them (Toor et al. 2006). Bioavailability of $\mathrm{P}$ in each residue can be difficult to predict.

There is an interest in finding a quick and easy way to assess $\mathrm{P}$ availability in any new material or residue. A number of chemical extraction methods have been tested, but predictability from these methods remain low (Brod et al. 2015a). A new method based physical diffusion, diffusive gradient in thin films (DGT) was originally developed to measure bioavailability of metals in natural waters (Davidson and Zhang 1994), and has also been developed to measure bioavailability in soil solution (Harper et al. 2000, Zhang et al. 2001). It has recently also been developed for P bioavailability in soils (Zhang et al. 2013) and it appears to predict plant available P better than any other single method (Mason et al. 2010, Tandy et al. 2011, Six et al. 2013).

A number of residues were assessed along with rock phosphate for $\mathrm{P}$ availability at two $\mathrm{pH}$ levels, and also use DGT to assess $P$ availability. 


\section{Materials and methods \\ Waste materials/P fertilizers}

Rock phosphate (RP) as well 7 residues/waste materials potentially used as sources of $\mathrm{P}$ in organic agriculture were tested. RP was obtained from Timac Agro, Austria (P26). One of the organic products was a commercially available product, Ladybug plus (LBP), a mixture of dried manure from chicken (20\%) mixed with bone meal (65-70\%) and vinasse (10-15\%). Other residues/waste materials were meat and bone meal (MBM), ash (ASH), wet composted food waste (CFW) and fish sludge (FS). MBM is waste from slaughterhouses and has been assessed in a number of previous studies (Jeng et al. 2004, 2006, Brod et al. 2012, 2014, 2015ab, Bøen et al. 2013). ASH is bottom wood ash originating from wood and mill residues (Brod et al. 2012, 2014, 2015ab). CFW is produced by Lindum, a Norwegian waste management company, by composting municipal food waste. Fish sludge (FS) is a residue from fish farming, containing fish faeces and fodder residues. Previous studies have indicated that composted and pelleted FS is a good nitrogen (N) and P fertilizer (Brod et al. 2012, 2014, 2015ab), here the untreated FS was tested. In addition there were two rest products from a farm sized biogas plant on an organic farm. In this plant, cow manure is first separated into a liquid and a solid (fibrous) fraction. The solid fraction is composted and the composted material was tested in this trial, vermicomposted solid manure (CSM). The liquid fraction is then anaerobically digested, and the digestate nitrified in a second reactor where air is stirred in. This fraction was then filtrated, and the solid filtrate was used in this trial, filtrated digestate (FD).

Table 1. Chemical composition of materials used in the experiment

\begin{tabular}{|c|c|c|c|c|c|c|c|c|}
\hline & $\mathrm{RP}$ & LBP & MBM & ASH & CFW & FS & CSM & FD \\
\hline Dry matter (\%) & 92.0 & 90 & 96.7 & 99.9 & 35.6 & 16.8 & 22.3 & 83.3 \\
\hline $\mathrm{pH}$ & 7.7 & & 6.5 & 12.2 & 8.3 & 5.7 & 9.1 & 9.7 \\
\hline Total carbon (\%) & & & & 1.0 & 35.4 & 45 & 38.1 & 36.9 \\
\hline Nitrogen (\%) & & 8 & 9.0 & & 2.3 & 7.6 & 2.7 & 4.1 \\
\hline Phosphorus (\%) & 11 & 4 & 4.5 & 2.2 & 0.70 & 2.4 & 1.3 & 1.4 \\
\hline Potassium (\%) & 0.39 & 5 & & 10 & 0.41 & 0.18 & 3.2 & 5 \\
\hline Calcium (\%) & 29 & 6 & 10 & 12 & 7.3 & 4.3 & 2.3 & 3.2 \\
\hline Magnesium (\%) & 1.6 & & & 1.9 & 0.22 & 0.42 & 0.75 & 8.4 \\
\hline Sulfur (mg kg-1) & 31000 & & 96 & 2900 & 0.24 & 6600 & 6000 & 6700 \\
\hline
\end{tabular}

\section{Pot trial}

To determine plant-available $P$ in waste materials and $P$ fertilisers, a pot experiment was conducted at two distinct soil pH levels. The experimental soil was a 9:1 (v/v) blend of nutrient-deficient sand and sphagnum peat. The sand represented typical soil from fluvial deposits in Norway. Sphagnum peat was mixed into the sand to increase the experimental soil's organic matter content and buffer capacity. To get the soil to two distinct $\mathrm{pH} \mathrm{CaCO}_{3}$ was added at a rate of $0.35 \mathrm{~g} \mathrm{~kg}^{-1}$ soil (low pH, approximately 5.32) and $0.9 \mathrm{~g} \mathrm{~kg}^{-1}$ (high pH, approximately 6.80). Lime and water (about a third of field capacity) was added 3 days before sowing and pots were left at the same temperature and moisture as during the growth trial to allow some equilibration. All nutrients apart from $\mathrm{P}$ were added at rates sufficient for optimal growth ( $0.3 \mathrm{~g} \mathrm{~N}$ and $\mathrm{K}, 0.0375 \mathrm{~g} \mathrm{Mg}$ as well as S and micronutrients) to all pots the day before waste materials were added and seeds were sown. Micronutrients were added as sulphates of Zn ( $\left.37.5 \mathrm{mg} \mathrm{pot}^{-1}\right)$, $\mathrm{Cu}\left(37.5 \mathrm{mg} \mathrm{pot}^{-1}\right), \mathrm{Mn}\left(37.5 \mathrm{mg} \mathrm{pot}^{-1}\right)$, Fe $\left(75 \mathrm{mg} \mathrm{pot}^{-1}\right)$, Mo $\left(0.75 \mathrm{mg} \mathrm{pot}^{-1}\right)$ and B $\left(3.75 \mathrm{mg} \mathrm{pot}^{-1}\right)$. Rates of nutrients were calculated to match fertilizer recommendations (Nibio 2003) based on $20 \mathrm{~cm}$ depth (100 kg ha-1 N and K, 30 $\mathrm{kg} \mathrm{ha}^{-1} \mathrm{P}$ at the optimal rate). Soluble $\mathrm{P}\left(\mathrm{Ca}\left[\mathrm{H}_{2} \mathrm{PO}_{4}\right]_{2}\right)$ was added to reference treatments at 0 , half optimal $(0.045 \mathrm{~g}$ pot $\left.^{-1}\right)$ and optimal rate $\left(0.09 \mathrm{~g} \mathrm{pot}^{-1}\right)$ at both $\mathrm{pH}$ levels. The waste materials/P fertilizers were added to other treatments at rates so that total $\mathrm{P}$ equalled $0.09 \mathrm{~g} \mathrm{pot}^{-1}$ (optimal level if all was available). There were three replicates of all treatments and pot size was $3 \mathrm{I}$. Soil and additions were mixed thoroughly, and all pots were watered to half field capacity. Pots were placed in growth rooms under 16 hour light, day/night temperature $18{ }^{\circ} \mathrm{C} / 12{ }^{\circ} \mathrm{C}$ and $60 \%$ relative humidity. Barley was sown at a rate of 20 seeds per pot, when all seeds had germinated (after 5 days) they were thinned to 15 plants in each pot. Pots were watered every 2-3 day initially to half field capacity, but to close to field capacity during periods of rapid growth. Pots were moved around in the growth room in a random manner each time they were watered as there were small differences in light levels. Plants were harvested by cutting 
the shoot just above the ground after ear emergence in all treatments, 56 days after sowing. P deficient plants reached ear emergence later than non-deficient plants. That meant that the most P starved plants had just reached ear emergence stage when harvested, whilst non-deficient plants had reached ear emergence up to two weeks earlier. Harvested plants were dried $\left(70^{\circ} \mathrm{C}\right)$, weighed and ground to a fine powder and analysed for total $\mathrm{P}, \mathrm{N}$ and $\mathrm{C}$.

\section{DGT measurements of $P$ availability}

The same soil and waste material mixtures as in the pot experiment as well as the soil from the harvested pots with the same treatment were used. Trays with $456 \mathrm{~g}$ dry soil were prepared and wetted to field capacity. They were then mixed well and incubated at $15{ }^{\circ} \mathrm{C}$ for a week and mixed again by stirring once in between. Then more water was added so that soil was saturated, the DGT probes were inserted, lid was put on and they were then incubated as prescribed by Hooda et al. (1999) for just over 48 hours again at $15^{\circ} \mathrm{C}$. The DGT probes were removed and analysed. There were three replicates of all treatments.

\section{Analyses}

Waste materials were analysed for chemical and physical properties, including total $\mathrm{P}$ and $\mathrm{N}$ by Eurofins using standard analytical procedures as in Brod et al (2015b). An exception was LBP where information from the manufacturer was used. The most important parameters from this analysis are in Table 1.

Plant samples (0.25-0.3 g) were digested in $5 \mathrm{ml}$ of ultrapure nitric acid in an UltraClave from Milestone at $260^{\circ} \mathrm{C}$. Samples were diluted to $50.0 \mathrm{ml}$ with DI water after digestion. P determination of plant samples were performed on an Agilent 8800 ICP-MS in oxygen reaction mode as a mass shift reaction 31P =>31P180.

P determination of DGT were performed by ICP-AES technique on IP10200 (Cambridge, UK). C and N were determined on Leco TruSpec CHN (St. Joseph, MI).

\section{Calculation and statistics}

Biomass production was regressed to soluble P using the following Mitscherlich type equation

$$
y=y_{0}+a\left(1-e^{-b x}\right)
$$

where $y$ is biomass or $\mathrm{P}$ uptake and $\mathrm{x}$ is soluble $\mathrm{P}\left(0,0.5\right.$ or 1 as a fraction of optimum) and $\mathrm{y}_{0}$, $\mathrm{a}$ and $\mathrm{b}$ are constants adapted for high and low $\mathrm{pH}$ separately. $\mathrm{P}$ uptake was regressed against soluble $\mathrm{P}$ and followed a linear equation:

$$
y=a x+b
$$

where $y$ is $P$ uptake and $x$ is soluble $P(0,1 / 2$ and 1$)$ as above and $a$ and $b$ are regression constants. Mineral fertiliser equivalent (MFE\%, Brod et al. 2012) for biomass and P uptake was calculated as:

$$
\operatorname{MFE}(\%)=\frac{x_{1}}{x_{\text {tot }}} \cdot 100
$$

where $x_{1}$ is $x$ calculated from the equations above ([1] for biomass production and [2] for $P$ uptake) and $x_{\text {tot }}$ is $x$ from the full fertiliser treatment.

The Mitscherlich type equation (1) was also used to regress DGT results to plant uptake. Then $\mathrm{x}$ was $\mathrm{P}$ uptake per hour in DGT and y was plant P uptake.

All statistical tests were performed in Minitab v. 15. A two-way ANOVA was used to determine if there was an overall effect of $\mathrm{P}$ source and $\mathrm{pH}$ (high or low). For each treatment high and low $\mathrm{pH}$ were also compared with a t-test. Some individual treatments were also compared with two-way Anova with $\mathrm{pH}$ and $\mathrm{P}$ source as factors. These tests were performed for biomass, $\mathrm{P}$ uptake in plants and in DGT. 


\section{Results \\ Biomass and $\mathrm{P}$ uptake}

$\mathrm{P}: \mathrm{N}$ ratios (Table 2) were within the ranges found by Ziadi et al. (2008) to indicate strong P limitation in wheat, except for the manure-based products, that were in a range where both $\mathrm{P}$ and $\mathrm{N}$ limitation are possible. The regression equations used to describe plant growth and P-uptake fitted well (Table 3).

Table 2. $\mathrm{N}$ and $\mathrm{P}$ concentration in plant tissue at harvest. Values are averages with standard error in brackets ( $\mathrm{n}=3$ ).

\begin{tabular}{|c|c|c|c|c|c|c|c|c|c|c|c|}
\hline & $0 P$ & $1 / 2 P$ & $1 \mathrm{P}$ & $\mathrm{RP}$ & LBP & MBM & ASH & CFW & FS & CSM & FD \\
\hline \multicolumn{12}{|l|}{ High pH } \\
\hline N (\%) & $\begin{array}{c}1.59 \\
(0.12)\end{array}$ & $\begin{array}{c}0.72 \\
(0.02)\end{array}$ & $\begin{array}{c}0.89 \\
(0.03)\end{array}$ & $\begin{array}{c}1.67 \\
(0.18)\end{array}$ & $\begin{array}{c}1.93 \\
(0.22)\end{array}$ & $\begin{array}{c}1.96 \\
(0.26)\end{array}$ & $\begin{array}{c}0.76 \\
(0.04)\end{array}$ & $\begin{array}{c}0.84 \\
(0.03)\end{array}$ & $\begin{array}{c}1.02 \\
(0.04)\end{array}$ & $\begin{array}{c}0.71 \\
(0.03)\end{array}$ & $\begin{array}{c}0.70 \\
(0.04)\end{array}$ \\
\hline$P\left(g_{k g}^{-1}\right)$ & $\begin{array}{c}0.64 \\
(0.02)\end{array}$ & $\begin{array}{c}0.95 \\
(0.04)\end{array}$ & $\begin{array}{c}1.37 \\
(0.07)\end{array}$ & $\begin{array}{c}0.62 \\
(0.02)\end{array}$ & $\begin{array}{c}0.67 \\
(0.02)\end{array}$ & $\begin{array}{c}0.69 \\
(0.01)\end{array}$ & $\begin{array}{c}0.79 \\
(0.03)\end{array}$ & $\begin{array}{c}0.62 \\
(0.08)\end{array}$ & $\begin{array}{c}0.68 \\
(0.04)\end{array}$ & $\begin{array}{c}1.30 \\
(0.05)\end{array}$ & $\begin{array}{c}1.08 \\
(0.06)\end{array}$ \\
\hline \multicolumn{12}{|l|}{ Low pH } \\
\hline N (\%) & $\begin{array}{c}2.26 \\
(0.63)\end{array}$ & $\begin{array}{c}0.70 \\
(0.04)\end{array}$ & $\begin{array}{c}0.90 \\
(0.02)\end{array}$ & $\begin{array}{c}1.42 \\
(0.12)\end{array}$ & $\begin{array}{c}1.59 \\
(0.04)\end{array}$ & $\begin{array}{c}2.10 \\
(0.23)\end{array}$ & $\begin{array}{c}0.72 \\
(0.03)\end{array}$ & $\begin{array}{c}0.80 \\
(0.01)\end{array}$ & $\begin{array}{c}0.87 \\
(0.04)\end{array}$ & $\begin{array}{c}0.70 \\
(0.02)\end{array}$ & $\begin{array}{c}0.74 \\
(0.03)\end{array}$ \\
\hline$P\left(\mathrm{~g} \mathrm{~kg}^{-1}\right)$ & $\begin{array}{c}0.75 \\
(0.07)\end{array}$ & $\begin{array}{c}0.94 \\
(0.04)\end{array}$ & $\begin{array}{c}1.23 \\
(0.05)\end{array}$ & $\begin{array}{c}0.62 \\
(0.02)\end{array}$ & $\begin{array}{c}0.67 \\
(0.01)\end{array}$ & $\begin{array}{c}0.73 \\
(0.00)\end{array}$ & $\begin{array}{c}0.76 \\
(0.03)\end{array}$ & $\begin{array}{c}0.67 \\
(0.03)\end{array}$ & $\begin{array}{c}0.70 \\
(0.03)\end{array}$ & $\begin{array}{c}1.27 \\
(0.03)\end{array}$ & $\begin{array}{c}1.23 \\
(0.03)\end{array}$ \\
\hline
\end{tabular}

Table 3. Regression coefficients prediction of biomass and $\mathrm{P}$ uptake for calculation of mineral fertiliser equivalent (MFE), and prediction of plant $P$ uptake based on DGT uptake

\begin{tabular}{lccccc}
\hline & $\mathrm{y}_{0}$ & $\mathrm{a}$ & $\mathrm{b}$ & $\mathrm{r}^{2}$ & $p$ \\
\hline Biomass & & & & & \\
High pH & 14.23 & 41.56 & 2.29 & 0.969 & $<0.0001$ \\
Low pH & 8.74 & 58.61 & 1.37 & 0.979 & $<0.0001$ \\
P-uptake & & & & \\
High pH & & 0.0615 & 0.0093 & 0.984 & $<0.0001$ \\
Low pH & & 0.0584 & 0.0061 & 0.969 & $<0.0001$ \\
P-uptake vs. DGT & & & & & \\
All & 13.36 & 42.04 & 1.07 & 0.523 & 0.0039 \\
High pH & 8.65 & 22.09 & 27.74 & 0.290 & 0.3581 \\
Low pH & 5.71 & 45.89 & 1.93 & 0.736 & 0.0183 \\
\hline
\end{tabular}

Both biomass (Fig. 1) and P uptake (Fig. 2) were significantly lower for all the waste materials than for the full soluble $\mathrm{P}$ (1P) treatment. The two animal manure based products (CSM and FD) performed best. ASH and FS and to a lesser extent CFW were almost comparable to the manure based products in terms of biomass production, but $P$ uptake was somewhat lower in those. MBM, LBP and RP where not significantly different from the no P (OP) treatment.

$\mathrm{P}$ source had an overall significant effect on biomass and $\mathrm{P}$ uptake $(p<0.05)$, but not $\mathrm{pH}$. There was also no significant difference between the high and low $\mathrm{pH}$ for any individual treatment for either biomass or $\mathrm{P}$ uptake.

\section{DGT}

There were relatively large differences between replicates and between some treatments in the DGT results (Fig. 3). The DGT results before growth showed an overall significant effect of material added $(p=0.005)$, and an almost significant effect of $\mathrm{pH}(p=0.09)$. However, there was a significant interaction $(p=0.003)$ between $\mathrm{pH}$ and waste material, meaning that the effect of $\mathrm{pH}$ is different for different waste materials. When different $\mathrm{pH}$ values were compared for each waste material, no significant differences were found. Very high values were recorded at the low pH for CSM (Fig. 3). Little or no residual P was found in most treatments. The exception was ASH and to some extent FS (Fig. 3). 
When the DGT results were regressed against plant uptake (Fig. 4), the very high value obtained by DGT for CSM at low $\mathrm{pH}$ had a large effect on the results. A relatively high $\mathrm{r}^{2}$ (Table 3 ) was therefore obtained at low $\mathrm{pH}$ and an intermediate value when all results were regressed together, whilst the value for high $\mathrm{pH}$ was low.

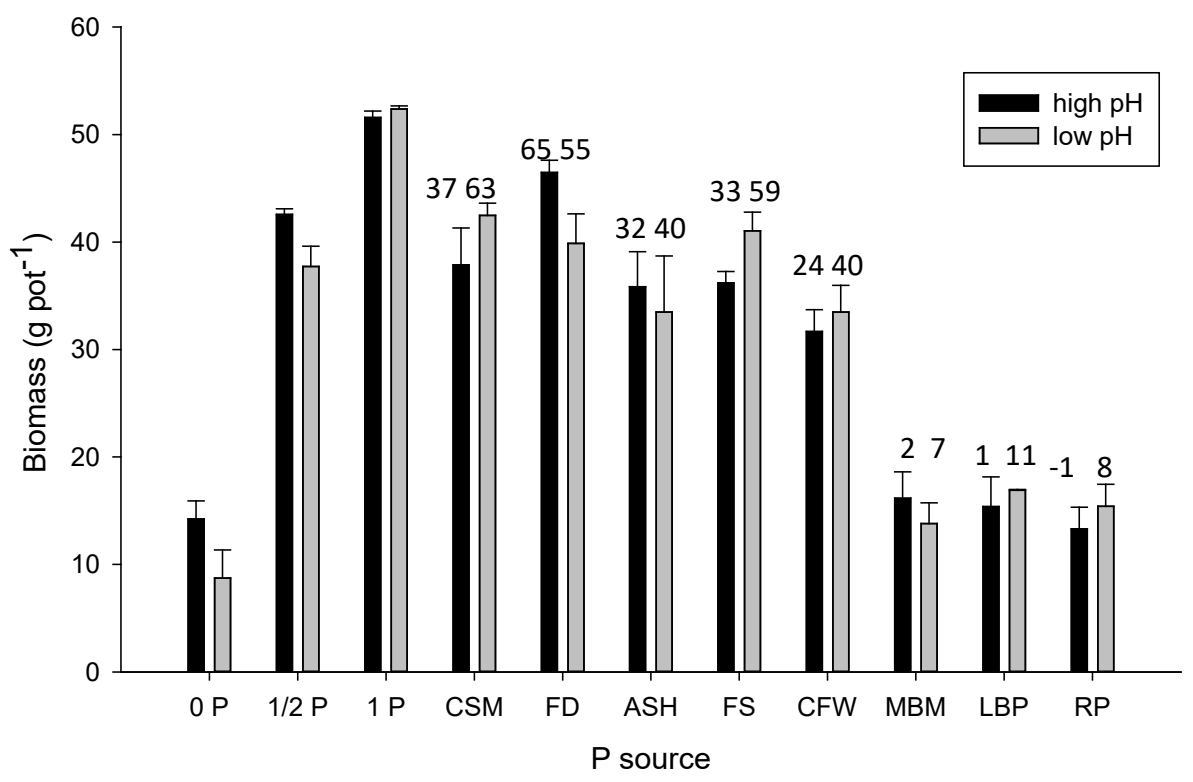

Fig. 1. Biomass production in aboveground biomass as a function of $P$ source. Error bars are standard error $(n=3)$. From left: no $P$, half optimal P, optimal P, followed by the various waste materials where total $\mathrm{P}$ addition in each was equal to optimal P. Mineral fertilizer equivalent for each P source are shown on top of each bar.

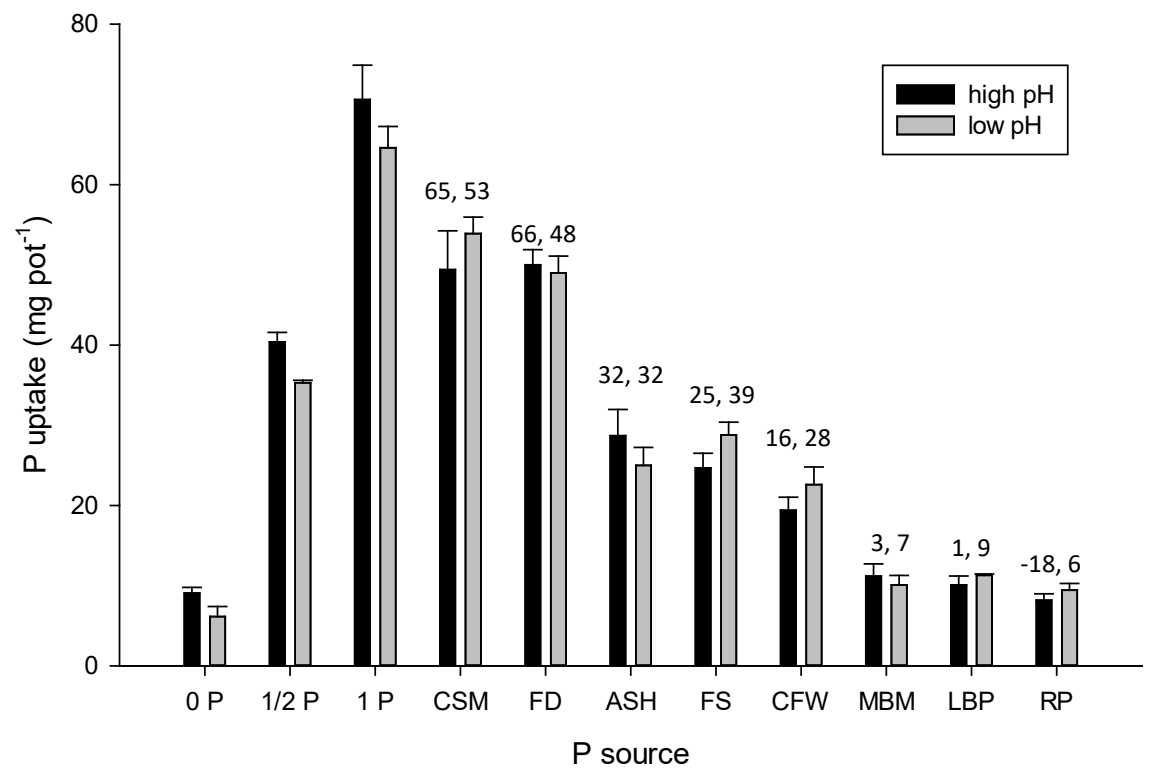

Fig. 2. Total $P$ uptake in aboveground biomass as a function of $P$ source. Error bars are standard error $(n=3)$. From left: no $P$, half optimal $P$, optimal $P$, followed by the various waste materials where total $P$ addition in each was equal to optimal $P$. Mineral fertilizer equivalent for each $P$ source are shown on top of each bar. 


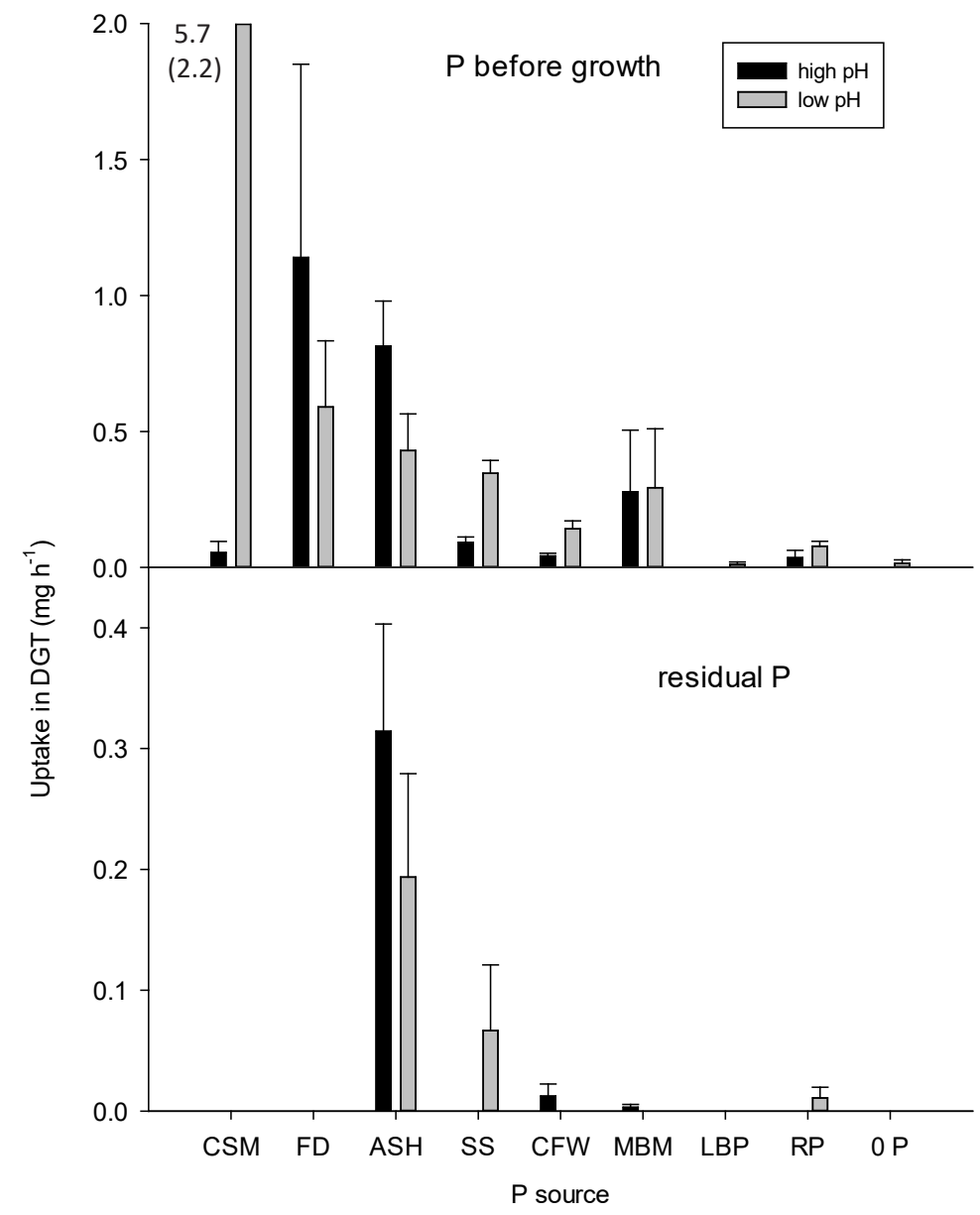

Fig. 3. Uptake of phosphorus in DGT probes per hour, before plant growth (top) and residual, after plant harvest (bottom). Error bars are standard error $(n=3)$. The very high value in the top graph is shown as a number beside the bar (standard error in brackets).

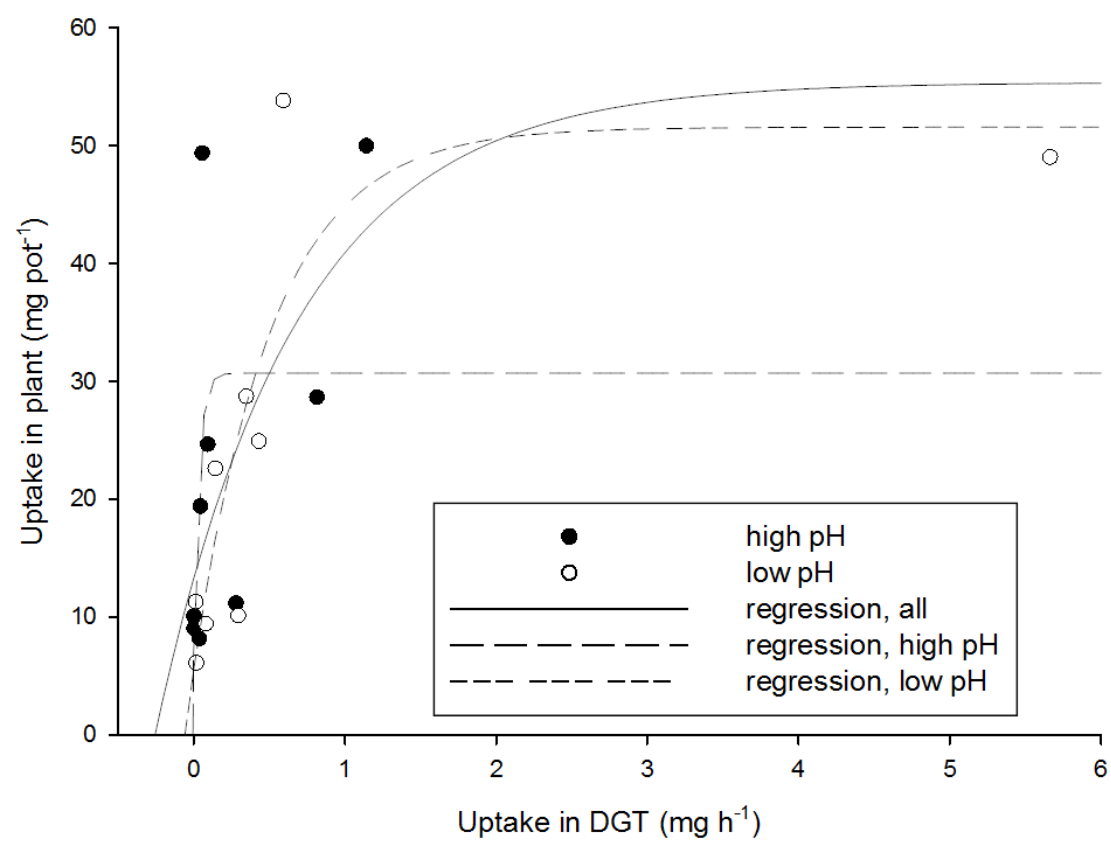

Fig. 4. Uptake in the plant as a function of uptake in DGT in the soil before plant growth. Points are averages $(n=3)$, filled circles show high $\mathrm{pH}$ treatments, open circles show low $\mathrm{pH}$ treatments. Regression lines for all treatments (solid line) and for each $\mathrm{pH}$ treatment separately (dotted lines) are shown. 


\title{
Discussion
}

\author{
Residues as P fertilisers
}

Rock phosphate, a product that is currently marketed as a P fertiliser for organic agriculture, had no measurable effect as a P fertiliser. Previous studies have also indicated that initial P availability to cereals is low (Vanlauwe et al. 2000ab), and that specific microbes and sulphur may be needed to solubilise it (Zabihi et al. 2011, Fan et al. 2012, Kaur and Reddy 2014). DGT also indicated that P availability for the next season's crop would not be any better. The commercial fertiliser product Ladybug plus and meat and bone meal also had almost no available $\mathrm{P}$ either the first or second season. Previous research has shown better P availability in meat and bone meal, although it depended on the type of meat and bone meal (Jeng et al. 2004, 2006, Bøen and Haraldsen 2013, Brod et al. 2014, Nogalska et al. 2014). In natural soil P will be released by decomposition of organic material, and in soils poor in P arbuscular mychorrhizal associations may increase P availability (Gollier et al. 2011). Ladybug plus is probably mainly used for $\mathrm{N}$ fertilization as $\mathrm{N}$ is the most limiting nutrient in most organic production systems. Therefore it may not have been noticed if the effect as a $P$ fertiliser is limited. The best $P$ availability was found in the animal manure based products. This is not surprising, as it has previously been shown that most $P$ in animal manure becomes soluble relatively quickly (Dao and Cavigelli 2003, Dao and Hoang 2008, Dao and Schwartz 2010). The concentrations of $\mathrm{N}$ and $\mathrm{P}$ in plant tissue even suggested that they may not have been strongly $\mathrm{P}$ limited at all. These results should be interpreted a bit cautiously, because the plants that grew best were also closer to maturity, and that may have influenced $\mathrm{N}$ and $\mathrm{P}$ concentrations in plant tissue as well. However, it is possible that growth was limited by $\mathrm{P}$ availability at certain stages during growth, but there may still not have been any $\mathrm{P}$ limitation at harvest. The DGT results suggested very high $\mathrm{P}$ availability in the vermicomposted product. Previous research has also indicated that vermicomposting makes nutrients, particularly P, more available (Gosh et al. 1999, Padmavathiamma et al. 2008). There is currently a plan to market the digestate-based product as a P fertiliser for stockless organic farming. The results from the present study suggest that it will perform better than most other waste-based products and certainly better than currently available commercial products. The other residues had intermediate $P$ availability. Particularly ash is interesting as a P source because the DGT results suggest that it also has significant residual $P$ availability. The $P$ fertilisation effect in the second season should be taken into account when ash is used. Future research should focus on how burning residues (completely or in pyrolysis) affect $P$ availability over several seasons. P in composted fish sludge has previously been found to be relatively available (Brod et al. 2012, 2014, 2015ab), the present study confirms that also P in fresh fish sludge is also moderately available.

\section{Use of DGT to study P availability}

Overall uptake in DGT was correlated to plant uptake. However, the DGT results showed much greater variability than the plant uptake results. The discrepancy between DGT and plant responses to high P availability is somewhat accounted for by using a nonlinear function that saturates at high availability. However, in our results, only one value was very high, and this one value had a large impact on overall fit $\left(r^{2}\right)$. There are several possible reasons for discrepancies between DGT results and plant uptake result. First, DGT was measured over 2 days, whilst the plant took up P over 2 months. That means that the plant could possibly also take advantage of $\mathrm{P}$ fractions that only become available slowly, whilst a relatively small $P$ fraction that is immediately available will have a large impact on the DGT results. There are also more fundamental differences between DGT and plant roots. First of all, insufficient mixing of residues into soil will have a much large impact on the DGT results than on plant uptake results, because plant roots will grow towards nutritious patches and proliferate within them, whilst DGT will take up P from its immediate surroundings. Although this problem was anticipated, and it was attempted to mix as well as possible, it was not possible to mix the residues $100 \%$ evenly into the soil. This can certainly explain that there were much larger differences between replicates in the DGT results than in the plant uptake results. Furthermore, plants will probably invest more in obtaining $\mathrm{P}$ when it is in short supply, so that differences between treatments tend to be smaller. Plants may for example be able to acidify the rhizosphere (Hoffland et al. 1989, Hinsinger 2001, Wouterlood et al. 2004) so that differences in pH in the bulk soil may not matter much for the plant, but does make a difference for DGT uptake. An overall effect of pH was found in the DGT results, but not in the plant uptake result. Most previous research on DGT has been on uptake of metals in concentrations well above those needed for plant growth (e.g. Davidson et al. 2000, Zhang et al. 2002), so that one would expect uptake to be determined by physical availability. Recent work on the correlation of $P$ uptake in plants and DGT have mostly been from tropical soils with high P sorption capacity (Mason et al. 2010, Six et al. 2013, 2014), where it can also be expected that physical availability determined uptake. Soils in temperate regions generally have lower sorption capacity than tropical soils, and it can therefore be expected that DGT will have somewhat lower predictive ability in those soils. It is possible that in non-adsorbing soils DGT should be seen as a "null hypothesis" that accounts for uptake as a physical and chemical process. Anything that is found to be different in the plant is caused by biology. This may be another possibly more fruitful use of the DGT system in soils with low sorption capacity than as a tool to assess bioavailability. 


\section{Conclusion}

Currently commercially available fertilizer products for organic agriculture appear to be inadequate as P fertilizers. Manure-based products are good P sources, and development of transportable products from manure for organic agriculture should be considered. Ash-based products are particularly interesting as they seem to provide plant available $\mathrm{P}$ over more than one season. Fish sludge is a good fertilizer products that is abundantly available in Norway, and use in organic agriculture should be considered.

\section{Acknowledgement}

The author wish to thank E. Brod, R. Pedersen, A.F. Øgaard and T.K. Haraldsen for advice on experimental setup and obtaining waste materials. The author also wishes to thank two anonymous reviewers and the editor for useful advice and editing of the manuscript. This study was funded by CORE Organic II "IMproved Phosphorus Resource efficiency in Organic agriculture Via recycling and Enhanced biological mobilisation" (IMPROVE-P), which aims to design improved $P$ recycling systems for organic farming.

\section{References}

Berry, P., Stockdale, E., Sylvester-Bradley, R., Philipps L., Smith, K., Lord, E., Watson C. \& Fortune, S. 2003. N, P and K budgets for crop rotations on nine organic farms in the UK. Soil Use and Management 19: 112-118. https://doi.org/10.1079/SUM2003176

Brod, E., Haraldsen, T. \& Breland T. 2012. Fertilization effects of organic waste resources and bottom wood ash: results from a pot experiment. Agricultural and Food Science 21: 332-347.

Brod, E., Haraldsen, T.K. \& Krogstad, K. 2014. Combined waste resources as compound fertiliser to spring cereals. Acta Agriculturae Scandinavica, Section B - Soil \& Plant Science 64: 329-340.

Brod, E., Øgaard, A.F., Haraldsen, T.K. \& Krogstad, T. 2015a. Waste products as alternative phosphorus fertilisers. Part II: Predicting P fertilisation effects by chemical extraction. Nutrient Cycling in Agroecosystems 103: 185-199. https://doi.org/10.1007/ s10705-015-9731-4

Brod, E., Øgaard, A.F., Hansen, E., Wragg, D., Haraldsen, T.K. \& Krogstad, T. 2015b. Waste products as alternative phosphorus fertilisers. Part I. Characterised inorganic P species affect fertilisation effects dependent on soil pH. Nutrient Cycling in Agroecosystems 103: 167-185. https://doi.org/10.1007/a10705-015-9734-1

Bøen, A. \& Haraldsen, T.K. 2013. Meat and bone meal and biosolids as slow-release phosphorus fertilizers. Agriculture and Food Science 22: 235-246.

Carpenter, S.R., Caraco, N.F., Correll, D.L., Howarth, R.W., Sharpley, A.N. \& Smith, V.H. 1998. Nonpoint pollution of surface water with phosphorus and nitrogen. Ecological Applications 8: 559-568. https://doi.org/10.1890/1051-0761(1998)008[0559:NPOSW W]2.0.CO;2

Cordell, D., Drangert, J.-O. \& White, S. 2009. The story of phosphorus: Global food security and food for thought. Global Environmental Change 19: 292-305. https://doi.org/10.1016/j.gloenvcha.2008.10.009

Cordell, D., Rosmarin, A., Schröder, J.J. \& Smit, A.L. 2011. Towards global phosphorus security: A system framework for phosphorus recovery and reuse options. Chemosphere 84: 747-758. https://doi.org/10.1016/j.chemosphere.2011.02.032

Dao, T.H. \& Cavigelli, M.A. 2003. Mineralizable carbon, nitrogen, and water extractable phosphorus release from stockpiled and composted manure and manure-amended soils. Agronomy Journal 95: 405-413. https://doi.org/10.2134/agronj2003.0405

Dao, T.H. \& Hoang, K.Q. 2008. Dephosphorylation and quantification of organic phosphorus in poultry litter by purified phytic-acid high affinity Aspergillus phosphohydrolases. Chemosphere 72: 1782-1787. https://doi.org/10.1016/j.chemosphere.2008.04.048

Dao, T.H. \& Schwartz R.C. 2010. Mineralizable phosphorus, nitrogen, and carbon relationships in dairy manure at various carbonto-phosphorus ratios. Bioresource Technology 101: 3567-3574. https://doi.org/10.1016/j.biortech.2009.12.070

Davison, W. \& Zhang, H. 1994. In-situ speciation measurements of trace components in natural waters using thin-film gels. Nature 367: 546-548. https://doi.org/10.1038/367546a0

Davison, W., Fones, G., Harper, M., Teasdale, P. \& Zhang, H. 2000. Dialysis, DET and DGT: in situ diffusional techniques for studying water, sediments and soil. In: Buffle, J. \& Horvai, G. (eds.). In Situ Monitoring of Aquatic Systems. Chemical Analysis and Specification. New York, USA: John Wiley \& Son Ltd. p. 495-569.

Fan, X.H., Schug, E., Haneklaus, S. \& Li, Y.C. 2012. In situ digestion of rock phosphates to mobilize Plant-available phosphate for organic farming. Communications in Soil Science and Plant Analysis 43: 2191-2201. https://doi.org/10.1080/00103624.2012.708073

Gollier, M.J., Wagentristl, H., Liebhard, P. \& Friedel, J.K. 2011. Yield and arbuscular mycorrhiza of winter rye in a 40-year fertilization trial. Agronomy for Sustainable Development 31: 373-378. https://doi.org/10.1051/agro/2010032

Gosh, M., Chattopadhyay, G.N. \& Baral, K. 1999. Transformation of phosphorus during vermicomposting. Bioresource Technology 69: 149-154. https://doi.org/10.1016/S0960-8524(99)80001-7

Harper, M.P., Davison, W. \& Tych, W. 2000. DIFS - a modelling and simulation tool for DGT induced trace metal remobilisation in sediments and soils. Environmental Modelling and Software 15: 55-66. https://doi.org/10.1016/S1364-8152(99)00027-4

Hinsinger, P. 2001. Bioavailability of soil inorganic $\mathrm{P}$ in the rhizosphere as affected by root induced chemical changes: a review. Plant and Soil 237: 173-195. https://doi.org/10.1023/A:1013351617532 
Hoffland, E., Findenegg, G.R. \& Nelemans, J.A. 1989. Solubilization of rock phosphate by rape II. Local root exudation of organic acids as a response to P-starvation. Plant and Soil 113: 161-165. https://doi.org/10.1007/BF02280176

Hooda, P.S, Zhang, H., Davidson, W. \& Edwards, A.C. 1999. Measuring bioavailable trace metals by diffusive gradients in thin films (DGT): soil moisture effects on its performance in soils. European Journal of Soil Science 50: 285-294. https://doi.org/10.1046/ j.1365-2389.1999.00226.x

Jeng, A., Haraldsen, T.K., Grønlund, A. \& Pedersen, P.A. 2006. Meat and bone meal as nitrogen and phosphorus fertilizer to cereals and rye grass. Nutrient Cycling in Agroecosystems 76: 183-191. https://doi.org/10.1007/s10705-005-5170-y

Jeng, A., Haraldsen, T.K., Vagstad, N. \& Grønlund, A. 2004. Meat and bone meal as nitrogen fertilizer to cereals in Norway. Agricultural and Food Science 13: 268-275.

Kaur, G. \& Reddy, M.S. 2014. Role of phosphate solubilizing bacteria in improving the soil fertility and crop productivity in organic farming. Archives of Agronomy and Soil Science 60: 549-564. https://doi.org/10.1080/03650340.2013.817667

Mason, S.D., McNeill, A., McLaughlin, M.J. \& Zhang, H. 2010. Prediction of wheat response to an application of phosphorus under field conditions using diffusive gradients in thin-films (DGT) and extraction methods. Plant and Soil 337: 243-258. https:// doi.org/10.1007/s11104-010-0521-0

Nibio 2003. Gjødslingshåndbok (Fertilizer Handbook). Ås, Norwegian Institute of Bioeconomy Research. Cited 2016. http:// www.bioforsk.no/ikbViewer/page/prosjekt/hovedtema?p_dimension_id=19190\&p_menu_id=19211\&p_sub_id=19191\&p_ $\operatorname{dim} 2=19602$.

Nogalska, A., Chen, L., Sienkiewicz, S. \& Nogalski, Z. 2014. Meat and bone meal as phosphorus supplier to cereals and oilseed rape. Agricultural and Food Science 23: 19-27.

Padmavathiamma, P.K., Li, L.Y. \& Kumari, U.R. 2008. An experimental study of vermi-biowaste composting for agricultural soil improvement. Bioresource Technology 99: 1672-1681. https://doi.org/10.1016/j.biortech.2007.04.028

Six, L., Smolders, E. \& Merckx, R. 2013. The performance of DGT versus conventional soil phosphorus tests in tropical soils-maize and rice responses to $\mathrm{P}$ application. Plant and Soil 366: 49-66. https://doi.org/10.1007/s11104-012-1375-4

Six, L., Smolders, E. \& Merckx, R. 2014. Testing phosphorus availability for maize with DGT in weathered soils amended with organic materials. Plant and Soil 376: 177-192. https://doi.org/10.1007/s11104-013-1947-y

Tandy, S., Mundus, S., Yngvesson, J., de Bang, T.C., Lombi, E., Schjoerring, J.K. \& Husted, S. 2011. The use of DGT for prediction of plant available copper, zinc and phosphorus in agricultural soils. Plant and Soil 346: 167-180. https://doi.org/10.1007/s11104011-0806-y

Toor, G.S., Hunger, S., Peak, J.D., Sims, T. \& Sparks, D.L. 2006. Advances in characterisation of Phosphorus in Organic wastes: Environmental and Agronomic Applications. Advances in Agronomy 89: 1-72. https://doi.org/10.1016/S0065-2113(05)89001-7

Van Kauwenbergh, S.J. 2010. World phosphate rock reserves and resources. Muscle Shoals, Alabama, USA, International Fertilizer Development Center. 48 p.

Vanlauwe, B., Diels, J., Sanginga, N., Carsky, R.J., Deckers, J. \& Merckx, R. 2000a. Utilization of rock phosphate by crops on a representative toposequence in the Northern Guinea savanna zone of Nigeria: response by maize to previous herbaceous legume cropping and rock phosphate treatments. Soil Biology \& Biochemistry 32: 2079-2090. https://doi.org/10.1016/S0038-0717(00)00150-4

Vanlauwe, B., Nwoke, O.C., Diels, J., Sanginga, N., Carsky, R.J., Deckers, J. \& Merckx, R. 2000b. Utilization of rock phosphate by crops on a representative toposequence in the Northern Guinea savanna zone of Nigeria: response by Mucuna pruriens, Lablab purpureus and maize. Soil Biology \& Biochemistry 32: 2063-2077. https://doi.org/10.1016/S0038-0717(00)00149-8

Watson, C.A., Bengtsson, H., Ebbesvik, M., Løes, A.K., Myrbeck, Å., Salomon, E., Schroder, J. \& Stockdale, E.A. 2002. A review of farm-scale nutrient budgets for organic farms as a tool for management of soil fertility. Soil Use and Management 18 (s1): $264-$ 273. https://doi.org/10.1079/SUM2002127

Wouterlood, M., Cawthray, G.R., Scanlon, T.T., Lambers, H. \& Veneklaas, E.J. 2004. Carboxylate concentrations in the rhizosphere of lateral roots of chickpea (Cicer arietinum) increase during plant development, but are not correlated with phosphorus status of soil or plants. New Phytologist 162: 745-753. https://doi.org/10.1111/j.1469-8137.2004.01070.x

Zabihi H.R., Savaghebi G.R., Khavazi K., Ganjali, A. \& Miransari, M. 2011. Pseudomonas bacteria and phosphorus fertilization, affecting wheat (Triticum aestivum L.) yield and $\mathrm{P}$ uptake under greenhouse and field conditions. Acta Physiologiae Plantarum 33: 145-152. https://doi.org/10.1007/s11738-010-0531-9

Zhang, G., Davison, W., Mortimer, R.J.G., Krom, M.D., Hayes, P.J. \& Davies, I.M. 2002. Localised remobilisation of metals in a marine sediment. Science of the Total Environment 296: 175-187. https://doi.org/10.1016/S0048-9697(02)00078-5

Zhang, H., Davison, W., Sun, B. \& Zhao, F.J. 2001. A new method to measure effective soil solution concentration predicts copper availability to plants. Environmental Science and Technology 35: 2602-2607. https://doi.org/10.1021/es000268q

Zhang, Y., Mason, S.D., McNeill, A. \& McLaughlin, M.J. 2013. Optimization of the diffusive gradients in thin films (DGT) method for simultaneous assay of potassium and plant-available phosphorus in soils. Talanta 113: 123-129. https://doi.org/10.1016/j. talanta.2013.03.023

Ziadi, N., Bélanger, G., Cambouris, A.N., Tremblay, N., Nolin, M.C. \& Claessens, A. 2008. Relationship between Phosphorus and Nitrogen Concentrations in Spring Wheat. Agronomy Journal 100: 80-86. https://doi.org/10.2134/agrojnl2007.0119 